\title{
Memoirs of the Plague: Lawfare
}

\section{Oscar Guardiola-Rivera ${ }^{1}$}

Accepted: 25 March 2021 / Published online: 17 May 2021

(c) The Author(s), under exclusive licence to Springer Nature B.V. 2021

\begin{abstract}
This is an entry into a collective journal of the twenty-first century years of plague. It introduces the notion of 'lawfare' by way of the contemporary case concerning Lula da Silva and Brazil's fall from grace. The latter is presented as an instance of violence in the international context, the managerial attitude to global disasters and, indeed, a plague. It chronicles the social struggles around the case and on that basis builds a somewhat playful manifesto for a new relationship between legal scholarship, the law school and the imaginary of permanent catastrophe and plague.
\end{abstract}

Keywords Cleansing · Digital colonialism · Jurisdictional accumulation · Lawfare · Principled alliances $\cdot$ Public secret $\cdot$ Stranger kin

Consider this entry in our collective journal of the twenty-first century years of plague. It was then, about the beginning of March 2018, after the passing of Marielle Franco, that among the rest of our neighbours, we heard in ordinary discourse that the plague was returned again in the Americas; for it had been very violent there, in the years before, whither, they say, it was brought, some said from North America, others from the colonising West, among the goods brought home by conquerors, military men and the merchant's fleet. It matters not from whence it came; but all agreed it was come into the Americas again. ${ }^{1}$

\footnotetext{
1 For the sources of paraphrases in the paragraph above, see Defoe (2011 [1722], p. 6), and Neuenschwander with Giraldes (2018). Also Taussig (2005).
}

Oscar Guardiola-Rivera

o.guardiola-rivera@bbk.ac.uk

1 School of Law, Birkbeck, University of London, London WC1E 7HX, UK 
For legal educators and activists, the plague and fire this time mean something else: politics by other means. Not just warfare but 'lawfare'. In Lawfare. An Introduction, Cristiano Zanin, Valeska Teixeira and Rafel Valim, define 'lawfare' as a tacti$\mathrm{cal} /$ strategic use of law to achieve more efficiently certain geopolitical, military and commercial objectives (Zanin et al. 2020).

This is violence at the international level (Fanon 2004). But there is something particularly strange about the emptying out of law's promissory language and rituals aimed as a weapon against clients like Lula or the lawyers themselves. ${ }^{2}$ Zanin and Teixeira, who represented Lula in court, speak of something anomalous vis-à-vis the principle of due process. And of law taking leave of any recognisable principle of ordering and justice.

They help us conjure up an image that does justice to the secret of lawfare: a public secret, war by other means. More efficient means whereby to achieve an initially hidden but in the end measurable objective: kill the reputation of a strong contender to the left of the political landscape of a country that was punching above the average weight of the Global South in international affairs. Lower his popular support. Regime change.

Further revelations of secret communications between officers in charge of the so-called Car Wash (Lava Jato) operation and the notorious judge Sergio Moro help truth coming to be in place of the veil: there was a collusion between members of the Judiciary, Brazil's General Prosecutor, the Federal Police and sectors of the worldwide corporate media as well as the global security/aid complex (the 'economic hitmen'). It aimed to selectively pursue and condemn political targets, all the while hitting the most important public companies in that country's economy. With devastating consequences for the emerging tricontinental BRICS alliance. ${ }^{3}$

Here comes the final revelation of the (public) secret of lawfare:

It is not possible to affirm all the members of the different institutions that participated in the plot were aware of the destructive power that the operation would have for the economic and political sovereignty of the country. That story will be told in time. What is known so far is that the collusion included clandestine commitments with agents and entities from other countries, especially the United States, and was responsible for the de-structuring of the productive model that had been adopted by the country in recent decades, especially the construction and energy producing chain. Those who understand that the target of lawfare is limited to selective persecution of leaders and [leftist] parties are mistaken. The legal war has proved strategically broad, flexible to each context in which it is undertaken and capable of achieving objectives of geostrategic interest in Latin America and the world. (Proner 2021, p. 2)

\footnotetext{
2 Brazil's former president, Luiz Inácio Lula da Silva.

3 Brazil, Russia, India, China and South Africa.
} 
The impact of lawfare goes beyond illegality and familiar jurisdictional boundaries. As Michael Taussig would put it, it is a kind of cleansing: social and economic cleansing (Taussig 2005, 2011, 2020; Garcia and Felipe 2019; Neuenschwander 2021).

More precisely, it aims to empty out a singular space from its producer inhabitants and their productions, institutional and economic. To take over that space, thereby gaining control over its producers and economic-institutional resources. Also, to dismantle them. So as to reassemble some of the resulting dividual fragments into spatiotemporal sets that could be reimagined as manageable assets and data. As such, their final destination could be calculated, judged and administered with the help of probabilistic modes of reasoning (Appadurai 2015; Appadurai \& Alexander 2019).

Some such assets would be judged valuable and bet for and against in horserace-like financial markets. Others will be judged disposable and let die by plague or hunger. Or in the case of the native peoples of the Amazon and in neighbouring Colombia, by a different choice of weapons. This is a cleansing plague. War by other means.

\section{III}

The argument so far: fragmented interests, assets and data, taken over and abstracted from their original concrete or individual producer and producing contexts, which are political-economic and socio-legal, can be submitted to processes of failure and governance by numbers. They can be bet for or against. They can be securitised, monetised and controlled, or digitally colonised and annexed to the presumed superior or 'purer' (less corrupt) jurisdiction. In this case, that of the US.

If so, as activist students of law and politics, we must renew our intellectual and pedagogical arsenals. First, another conception of law: let us shift the standpoint of legal analysis and education from traditional Particular to critical General Jurisprudence. Second, let us teach not only beyond the discipline but also explore the beyond of given legal cultures or families; beyond their well-determined provinces, historical inheritances, taken-for-granted prejudices and assumptions. Third, we need stranger alliances of kin (De Sousa Santos 2002; Douzinas and Gearey 2005; Twining 2004, 2009; Haraway 2016; Gordon 2020).

This is what Adam Gearey and I have been attempting in the virtual space of our 'Law, Theory, Virus' Workshop. From China to Brazil. With others. There emerges a proposal to build a common Legal Theory syllabus, which could be taught in Bogotá, Hong Kong, Stanford or Rio. Not only with colleagues and students, also other others. The idea is to free the study of law and literature in Eastern/Western academia from its dependence on the premise that literature, civility and institutional attitudes begin with letters. Not just the 'black letter' of the law but also, or rather, letters and simulation in general. Practices that tend to treat anything otherwise as a relic of past history.

This is a call to arms: to harness the untapped possibilities of academia's move outdoors and online to make kin with the theories and practices of reconstructed 
ethnography, artistic practices, counter-forensics and speculative practices here and elsewhere: from science fact to speculative fiction, native storytelling, speculative geographies \& boundaries, or the scientific critique of his-story and economic figurations. Also, speculative anthropologies and feminisms, and spatiotemporal forensic architectures (Lindahl 2013; Alonso Bejarano 2019; Gearey 2019; GuardiolaRivera 2019; Weizman 2019; Escobar 2020; Garcia Edgar 2020).

What for? To make kin and stay with the problem. To carry the fetish in more combative/constructive ways rather than pretending we can smash it by exposing the secret to the usual forensic/interpretive procedures. It is not enough to interpret our world of institutional phantoms and simulations. When turned into a mass-media spectacle, these phantoms and simulations may become more self than ourselves and root hopelessness into our legal-political hearts. And in the minds of citizensubjects. Hence our law and imagination of 'anomalous' crises and permanent plague, as the Brazilian case demonstrates.

\section{IV}

Let us be clear. This is digital colonialism and self-colonisation as much as it is a form of accumulation by dispossession, and jurisdictional accumulation. In toto, this is global disaster management and governance by means of numbers, data and regulatory matrixes and metrics. As in the cases of Covid-19 management in the West, or monetised- and forced-failure as well as lumpen-development in the Rest (Fanon 2004, 2018; Amin 2019; Appadurai and Alexander 2019; Izhar 2020; Pal 2020; Supiot 2020).

These imaginary phantoms and simulations threaten to erase the traces of mass utopias of the last century. For instance, Tricontinentalism, in the East, the West and the Rest (Garland-Mahler 2018).

Imperfect though these utopias were, everything is, they not only intensified the importance of everything that exists but also taught us never to confuse what just is with justice. They are being banned as absolute violence and vanished. By exhibiting them as mere relics in legal archives, museums, mainstream academic syllabuses, transitional justice and history tribunals, and consumable art-and-media exhibitions. Or else, by pricing the expository value of these items, passing such productive enterprises as if they were producing themselves. To bet for and against them in the auction houses of accelerated finance Capitalism. Thereby slowly cancelling the future.

That is why the impact of 'lawfare' operations and other simulations can be measured and expressed in numbers. It is likely that the current Brazilian government will blame it on Covid-19 just as the British government is blaming the virus for the devastation caused by the stealth privatisation of the health and other public sectors during years of conservative and ultra-liberal rule and Brexit. Never mind. In political economic terms, this is the real plague. ${ }^{4}$

\footnotetext{
4 According to a study by the Inter-Union Department of Socio-Economic and Statistical Studies of Brazil (DIEESE) the catastrophic impact of Lava Jato, masked under the military and simulated-moral language of the war against corruption can be measured thus: over three million jobs have vanished from
} 
The use of standardising norms, normative orders and regulations as weapons of war is not new. It is not the 'new normal'. But neither is it the same as the older exceptionalism either. Rather, this is the point where some new things meet some very old things. The old story rehashed in the terms of new technologies, legal and otherwise.

It is well-known that those who now use lawfare are the same ones who used to denounce it as a tool in the hands of the human rights and tricontinental organisations of the immediate past. So as to demonise them as false humanitarians, internationalists or globalisers, utopians interested in putting an end to permanent warfare.

This may seem paradoxical, at first. The same United States, which did so much to build the post-war architecture of world peace and human rights based on the rule of law 'to save succeeding generations from the scourge of war', which once denounced lawfare as a tool in the hands of transcontinental organisations so as to demonise them, would have come to see law as one of the weapons to fight a global civil war seen now as natural and unavoidable. ${ }^{5}$

But the paradox dissolves once we accept that the US projects its own internal tensions outside, onto the skin of more or less real, simulated and denigrated enemy others who can then be blamed for such contradictions. Anthropologists call this the 'scapegoating mechanism'. Writers see here a reformulation of the old story about 'evil' others into a 'new problem' (Fisher 2014). If so, as legal analysts and educators we must shift our perspective concerning the relationship between law and internalised morality as well as our attitudes toward confessional behaviour. Indeed, how best to disavow our responsibility for our own contradictions than to blame presumed 'evil' others, foreign agents, and enemies of the fatherland?

\section{V}

It is not enough to describe and interpret our familiar jurisdictional prison-houses or to come up with 'techno-regulatory fixes' for our confined cities. As Fisher would say, and before him Ernesto Laclau (2004), we also need to locate the windows and the cracks in our houses. To crack them open and let in the light outside.

Once we accept this, we can start making sense of the genealogy of this perverse regulatory framework. It is half-moral-spectacle, half-colonial-pragmatism.

In the case of lawfare, back to the strategic lawsuit against public participation during the War on Terror, Plan Condor and Plan Colombia. Or, further back, to the 1961 Single Convention on Narcotic Drugs and other instances of the extraterritorial extension of US jurisdiction. All of which can be traced back to the re-imagination

\section{Footnote 4 (continued)}

the Brazilian economy in record time, in the construction and energy sectors. A reduction in net and real salaries of some 50 billion Reais for actual Brazilian people. Overall, a contraction of $2.6 \%$ of Brazil's GDP after the country achieved remarkable levels of economic success during the first decade of the twenty-first century. See Proner, 2021.

5 For quote, see United Nations Charter (1945), Preamble, available at https://www.un.org/en/about-us/ un-charter 
of the US as a 'legalist' empire after often-ignored episodes like the Spanish-American, Mexican-American, or Indian wars, and the Civil War, by people often hailed as heroes in the mainstream his-story and philosophy of law and human rights. Despite the fact such imaginary incarnated the worst tenets of white-settler colonialism: the Frontiersmen myth; Manifest Destiny; the Scholasticism of 'natural' property rights and slavery; and other terminal creeds in the 'literature of dominance' (Vizenor 2008, 2012; Allen Coates 2016). ${ }^{6}$

These are part and parcel of the renewal of older dreams of harmony through calculation and a world without others. For many years these have informed external and internal forms of colonialism. What is new is the redescription of these older tenets in the language of cybernetics and systems regulation. As in the dream of society's 'auto-pilot', dear to today's neuroscientists and behavioural economists. For use by CEOs, the 'regulators' of national/supra-national systems and the designers of the catastrophic Covid-19 policy established by Brazilian and British governments. 'Catastrophic' in the sense that these policies void us of hope, endlessly having to adapt to the nudges and regulations dreamed up by patriarchs and humourless clown figures.

To the point where law itself has been reduced to 'regulation', and the search for good government and life under just laws seemingly abandoned for the mere efficiency of calculated goals and achievements measurable by way of metrics. Such as magnitudes and so-called performance metrics. They have also reared their ugly heads in higher education frameworks. Thereby becoming the true 'cancel cultures' of governance by numbers (Supiot, 2009, 2020).

Our task in the new normal of the old normal is to carefully, critically distinguish, as legal educators and active advocates, between law as a model of allegiance (governance) and law as a principle for making alliances with strangers (making kin) in the interest of improving basic conditions of life (rights, good government and Buen Vivir). As citizens, it is to take position in these alliances of stranger kin, generations and social classes, to engage in active combat or protest in the courts, the streets and the ballot box. What for? To awake from the dreams and nightmares of our parents. To fight against the poverty of society. To transform law and society rather than merely interpreting it.

\section{References}

Allen Coates, Benjamin. 2016. Legalist empire international law and American foreign relations in the early twentieth century. Oxford: Oxford University Press.

Alonso Bejarano, Carolina. 2019. Decolonizing ethnographies. Undocumented immigrants and new directions in social science. Durham: Duke University Press.

Amin, Samir. 2019. The new imperialist structure. Monthly Review 71 (3), posted 1 July 2019, Available at https://monthlyreview.org/2019/07/01/the-new-imperialist-structure/ Accessed 30 March 2021.

\footnotetext{
6 The 1961 Single Convention is the only one of its kind to include the language of 'evil', as Kojo Koram has shown (Koram 2018). But it shares such peculiarity with the malum prohibitum of Plans Colombia and Condor as well as the US Foreign Agents Act of the 1930s.
} 
Appadurai, Arjun. 2015. Banking on words. The failure of language in the age of derivative finance. Chicago, Ill.: University of Chicago Press.

Appadurai, Arjun, and Neta Alexander. 2019. Failure. Cambridge: Polity Press.

Defoe, Daniel. 2011. 1722. A journal of the plague year: Digireads.com Publishers.

Douzinas, Costas, and Adam Gearey. 2005. Critical jurisprudence. The political philosophy of justice. London: Hart/Bloomsbury Press.

Escobar, Arturo. 2020. Pluriversal politics. The real and the possible. Durham, NC.: Duke University Press.

Fanon, Frantz. 2004 [1961]. The wretched of the earth. New York: Grove Press.

Fanon, Frantz. 2018. Alienation and freedom, ed. J. Khalfa and R.J.C. Young. London: Bloomsbury.

Fisher, Mark. 2014. The new problem of evil. In Aesthetic justice. Intersecting artistic and moral perspectives, Part 1, Chapter 1, ed. P. Gielen and N. Van Tomme. Amsterdam: Valiz.

Garcia Arboleda, Juan Felipe. 2019. El exterminio de la Isla de Papayal. Etnografias sobre el estado y la construcción de paz en Colombia. Bogotá: Editorial Javeriana.

Garcia, Edgar. 2020. Signs of the Americas. A poetics of pictography, hieroglyphs and Khipu. Chicago: University of Chicago Press.

Garland-Mahler, Anne. 2018. From the tricontinental to the global south. Race, radicalism, and transnational solidarity. Druham, CN.: Duke University Press.

Gearey, Adam. 2019. Poverty law and legal activism. Lives that slide out of view. London: Routledge/ Glasshouse Books.

Gordon, Lewis R. 2020. Freedom, justice, and decolonization. London: Routledge.

Guardiola-Rivera, Oscar. 2019. In defence of armed/art struggle. Bogotá, London: UTadeo.

Haraway, Donna J. 2016. Staying with the trouble. Making kin in the Chthulucene. Durham, NC.: Duke University Press.

Izhar, Siraj. Prisoners of state (Critique in times of Coronavirus), in Critical Legal Thinking, posted 28 April 2020, Available at https://criticallegalthinking.com/2020/04/28/prisoners-of-state-critique-intimes-of-coronavirus/ Accessed 30 March 2021.

Koram, Kojo. 2018. The sacrificial international: The war on drugs and the imperial violence of law, Doctoral thesis supervised by O. Guardiola-Rivera at Birkbeck, University of London. http://bbkth eses.da.ulcc.ac.uk/307/. Accessed 1 March 2021.

Laclau, Ernesto. 2004. Ethics, normativity and the heteronomy of law. Read in response to a lecture by Simon Critchley in the Albert Schweitzer Series on Ethics and Politics at New York University, Available http://www.politicaltheory.info/essays/laclau.htm Accessed 1 March 2021, reprinted in 2014 as part of The rhetorical foundations of society. London \& New York: Verso.

Lindahl, Hans. 2013. Fault lines of globalisation. Legal order and the politics of a-legality. Oxford: Oxford University Press.

Neuenschwander, Juliana, (with Marcus Giraldes). 2018. Marielle Franco: 1979-2018. New Left Review 110 (Mar/Apr), https://newleftreview.org/issues/ii110/articles/juliana-neuenschwander-marcus-giral des-marielle-franco-1979-2018. Accessed 1 March 2021.

Neuenschwander, Juliana. 2021. Presentism, pandemic and crisis: An unexceptional plague. Paper delivered at the Law, Theory, Virus Workshop, 26 February.

Pal, Maïa. 2020. Jurisdictional accumulation. An early modern history of law, empires, and capital. Cambridge: Cambridge University Press.

Proner, Carol. 2021. Operação Lava Jato e Relações Externas. Manuscript on file with the author.

Santos, Boaventura de Sousa. 2002. Toward a new legal common sense: Law, globalisation and emancipation. London: Butterworths.

Supiot, Alain. 2009. Homo juridicus. Essai sur la function anthropologique du droit. Paris: Seuil.

Supiot, Alain. 2020 [2015]. La gouvernance par les nombres: Cours au Collège de France, 2012-2014. Paris: Hachette Pluriel. English version. Governance by numbers. The making of a legal model of allegiance. London: Bloomsbury, Paperback edn.

Taussig, Michael. 2005. Law in a lawless land. Diary of a Limpieza in Colombia. Chicago: University of Chicago Press.

Taussig, Michael. 2011. Fieldwork notebooks. Kassel: HatjeCantz.

Taussig, Michael. 2020. Mastery of non-mastery in the age of global meltdown. Chicago: University of Chicago Press.

Twining, William. 2004. Diffusion of law: A global perspective. In The Journal of Legal Pluralism and Unofficial Law 36 (49): 1-45. Taylor \& Francis. https://doi.org/10.1080/07329113.2004.10756300 
Twining, William. 2009. General jurisprudence. Understanding law from a global perspective. Cambridge: Cambridge University Press.

Vizenor, Gerald, (with Jill Doerfler), et al. (eds.). 2008. Survivance. Narratives of native presence. Lincoln: University of Nebraska Press.

Vizenor, Gerald, (with Jill Doerfler), et al. (eds.). 2012. The white earth nation. Ratification of a native democratic constitution. Lincoln: University of Nebraska Press.

Weisman, Eyal. 2019. Forensic architecture. Violence at the threshold of detectability. Princeton, NJ: Zone Books/Princeton University Press.

Zanin, Cristiano, Valeska Teixeira, and Rafael Valim. 2020. Lawfare. Uma Introdução. Coimbra: Almedina.

Publisher's Note Springer Nature remains neutral with regard to jurisdictional claims in published maps and institutional affiliations. 